\title{
A second locality for the Namib darkling beetle Onymacris brainei (Tenebrionidae, Coleoptera) and first report on its molecular phylogenetic placement
}

\author{
Trip Lamb', Eugene Marais², Jason E. Bond ${ }^{3}$ \\ I Department of Biology, East Carolina University, Greenville, NC 27858, USA 2 National Museum of Na- \\ mibia, Windhoek, Namibia 3 Department of Biological Sciences and Auburn University Museum of Natural \\ History, Auburn University, Auburn, AL 36849, USA \\ Corresponding author: Trip Lamb (lamba@ecu.edu) \\ Academic editor: A. Smith | Received 12 May 2017 | Accepted 19 July 2017 | Published 1 August 2017 \\ http://zoobank.org/62C77060-6427-46AD-88B6-AD71BA3C9A1E \\ Citation: Lamb T, Marais E, Bond JE (2017) A second locality for the Namib darkling beetle Onymacris brainei \\ (Tenebrionidae, Coleoptera) and first report on its molecular phylogenetic placement. ZooKeys 687: 63-72. https:// \\ doi.org/10.3897/zookeys.687.13660
}

\begin{abstract}
Onymacris brainei Penrith, 1984 - the most recent species of Onymacris to be described - is known only from its type locality in the Namib Desert, adjacent to the Cunene River in northern Namibia. No additional specimens are known to have been collected beyond the type series. Herein, we report on eight specimens discovered at a second site near the original locality. DNA from four beetles was used to determine the phylogenetic placement of $O$. brainei among congeners, based on sequence data from one nuclear (histone III) and two mitochondrial $(\operatorname{cox} 1, \operatorname{cox} 2)$ genes. Maximum likelihood analysis identifies $O$. brainei as a member of the 'white' Onymacris clade, in which it forms a strongly supported subclade with $O$. bicolor and $O$. marginipennis. More broadly, its phylogenetic placement augments previous molecular results that revealed a sister taxon relationship between the 'white' Onymacris and a second genus, Physadesmia. The paraphyly of Onymacris with respect to Physadesmia highlights a need for nomenclatural change, but revision should await acquisition of genetic data for the few species outstanding in both genera.
\end{abstract}

\section{Keywords}

Adesmiini, Namib Desert, Onymacris, Tenebrionidae

Copyright Trip Lamb et al. This is an open access article distributed under the terms of the Creative Commons Attribution License (CC BY 4.0), which permits unrestricted use, distribution, and reproduction in any medium, provided the original author and source are credited. 


\section{Introduction}

The darkling beetle genus Onymacris is a diverse assemblage of fast-running diurnal species endemic to Africa's Namib Desert and adjacent southwestern edges of the Kalahari. As substrate specialists, these beetles are restricted to loose sand that characterizes hummocks, dry riverbeds, and dune fields, where they occur in abundance and assume key ecological roles as detritivores (Louw 1983; Hanrahan and Seely 1990). The genus belongs to the flightless tribe Adesmiini, which includes 240+ species and is distributed largely within southwest Africa-a geographic center where adesmiines exhibit their greatest ecological breath and morphological diversity (Koch 1962; Penrith 1979). Regionally, Onymacris represents one of the tribe's more species-rich genera, with 26 currently recognized taxa (14 species and 12 subspecies) that include distinctive 'white' species, whose elytral color ranges from pure white to yellow or $\tan$ (Fig. 1). White elytral coloration, an unusual characteristic among beetles in general and darkling beetles in particular, is one of many remarkable evolutionary features observed among Namib tenebrionids that are unknown in beetles from other deserts (Hamilton and Seely 1976; Endrödy-Younga 1978; Roberts et al. 1991).

'White' Onymacris are restricted to the northern Namib, where they are patchily distributed, often with limited geographic ranges. Onymacris brainei-the most recent member of the genus to be described (Penrith 1984)-represents this case in the extreme: it is known only from the type locality in northern Namibia, just south of the Cunene River along the Angolan border (Fig. 2). Steven Braine collected the first specimens (3 males, 2 females) on 24 February 1983 and brought them to the attention of Mary-Louise Penrith, who at that time was actively revising the southern African Adesmiini (Penrith $1975,1979,1984,1986)$. Early in the following year (12-15 February 1984), Penrith and Ruth Müller collected 16 additional specimens at the original locality, which provided sufficient material for describing the new species, named in Braine's honor (Penrith 1984). Onymacris brainei is distinguished from other 'white' species by the presence of three broad, pale yellow to tan stripes on otherwise white elytra (Fig. 3).

To our knowledge, no other specimens or localities for O. brainei have been documented since its description. In 2015, some 30 years after Penrith and Müller's expedition, we searched the general vicinity of the type locality in an attempt to update the status of $O$. brainei. Herein, we report on eight additional specimens taken from a second site. Importantly, these beetles provided a source of fresh tissue for DNA extraction, gene sequencing, and phylogenetic analysis. Hence we also offer the first report on the molecular phylogenetic placement of $O$. brainei among its congeners.

\section{Methods}

\section{Field survey for Onymacris brainei}

Penrith (1984) reported the type locality as "Kunene R. east of dunes at 17.12S, 12.10E," where beetles were collected "on dune hummocks." Working from this geographic ap- 

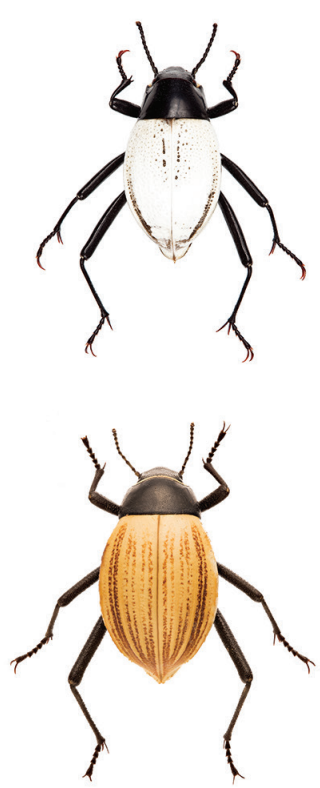
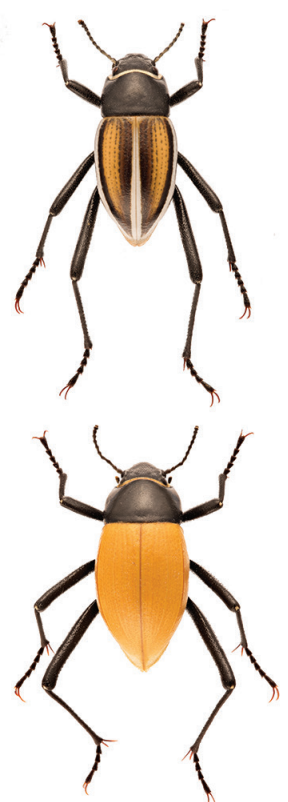
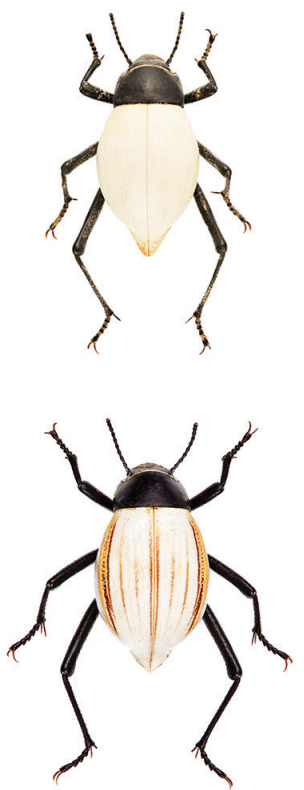

Figure I. Color variation among members of the 'white' Onymacris clade, as represented by: (top row, left to right) Onymacris bicolor, O. marginipennis, O. candidipennis, and (bottom row, left to right) O. langi visseri, O. langi cornelii, and $O$. langi meridionalis.

proximation, we searched a series of appropriate sites (i.e., vegetated hummocks) across the region on 21-22 May 2015. Three of these sites yielded other white Onymacris (O. bicolor, O. langi cornelii), and at a fourth, final site $\left(17^{\circ} 17.87^{\prime} \mathrm{S} ; 12^{\circ} 06.20^{\prime} \mathrm{E}\right)$, we succeeded in locating $O$. brainei (Fig. 2). Several beetles were observed, of which eight specimens were captured, euthanized (ethanol injection), and carded.

\section{Molecular phylogenetic analysis}

Rear legs from four of the eight beetles were preserved in RNAlater for subsequent DNA isolation using Qiagen's DNeasy kit. The mitochondrial genes cytochrome oxidase I ( $\operatorname{cox} 1)$ and cytochrome oxidase II ( $\cos 2)$ and a nuclear gene (histone III, H3) were amplified using the primers and PCR conditions listed in Table 1. Amplicons were cleaned using exoSAP-IT (USB Corp.) and sequenced on an Applied Biosystems 3130 capillary sequencer. Sequences were edited and assembled in Sequencher 4.9 (GeneCodes, Ann Arbor, MI) and aligned using ClustalX ver. 2.0 (Larkin et al. 2007), after which sequences were translated to ensure a correct reading frame. Sequences are available through GenBank (Table 2).

DNA sequences for $O$. brainei were combined with sequence data previously generated for Onymacris (Table 2) to yield a concatenated dataset-cox1 (1212 bp), cox2 (688 bp), and $H 3$ (317 bp)-representing 18 of the 26 currently recognized species/ 


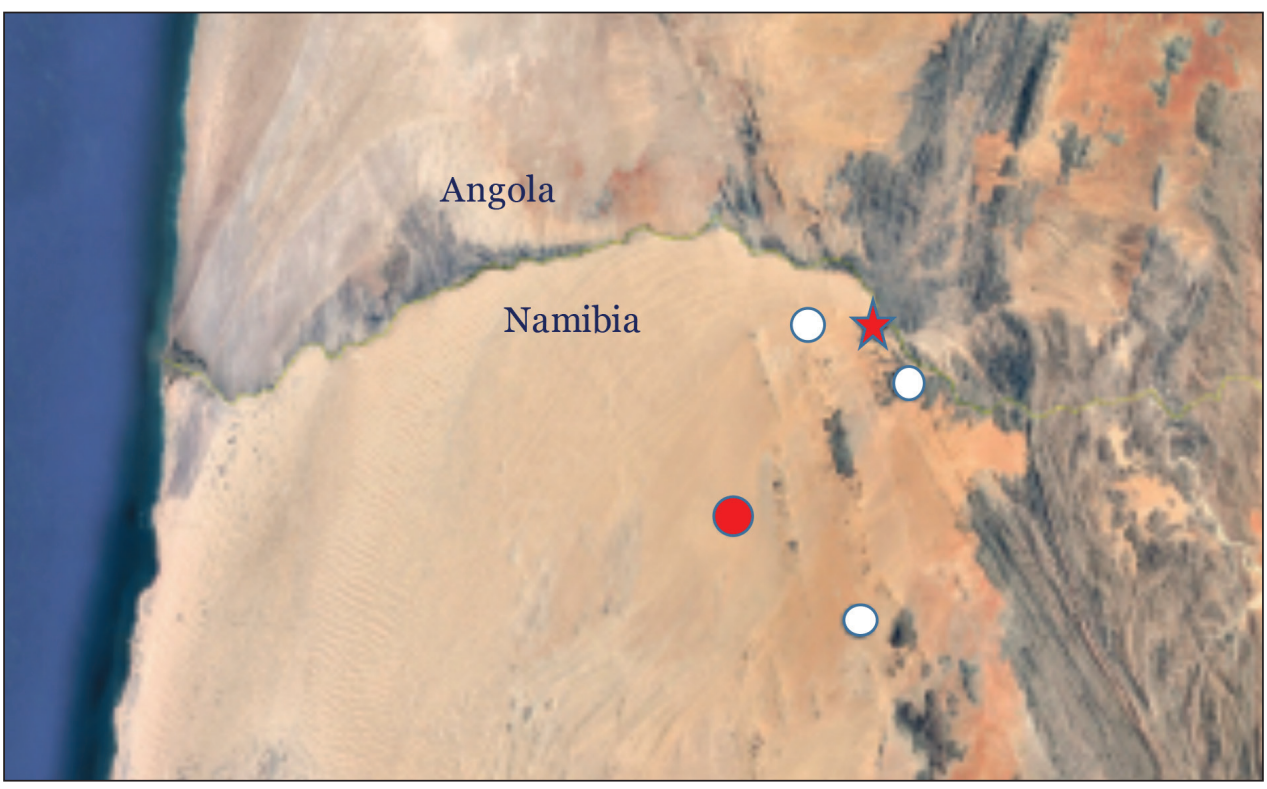

Figure 2. Map illustrating the type locality for Onymacris brainei (star), surveyed sites with appropriate habitat (white circles), and the second locality for $O$. brainei (red circle).

Table I. PCR primers and amplification conditions.

\begin{tabular}{|c|c|c|c|c|}
\hline Gene & Primer & Annealing & Cycles & Reference \\
\hline \multirow[b]{2}{*}{$\cos 1$} & TY-J-1460 & $50^{\circ} \mathrm{C}$ & 35 & \multirow{4}{*}{ Simon et al. (1994) } \\
\hline & $\frac{\text { TL2-N-3014 }}{\text { C1-I-2183 }}$ & sequencing only & (5) & \\
\hline \multirow[b]{2}{*}{$\cos 2$} & TL2-J-3037 & \multirow[b]{2}{*}{$50^{\circ} \mathrm{C}$} & \multirow[b]{2}{*}{35} & \\
\hline & TK-N-3785 & & & \\
\hline \multirow{2}{*}{ H3 } & Hex AF & \multirow{2}{*}{$61.5^{\circ} \mathrm{C}$} & \multirow{2}{*}{45} & \multirow{2}{*}{ Odgen and Whiting (2003) } \\
\hline & Hex AR & & & \\
\hline
\end{tabular}

subspecies. Those taxa unavailable to us for sequencing included $O$. candidipennis and $O$. langi langi, both 'white' beetles from Angola, as well as the 'black' beetles $O$. plana debilis and $O$. paiva conjuncta (though our dataset contains their nominate subspecies). We also incorporated species sequences representing three additional adesmiine genera: Physadesmia (represented by $P$. globosa), shown to be the sister taxon to the white Onymacris clade (Lamb and Bond 2013) as well as Eustolopus octoseriatus and Adesmia cribripes, which served as outgroups.

We used maximum likelihood (ML) to analyze the concatenated gene dataset. The ML analysis, executed in RAxML ver. 7.2.8 (Stamatakis 2006), comprised 1,000 random sequence addition replicates (RAS) using the commands "-\# 1000" and "-m GTRGAMMA." Bootstrap support values were calculated using the same search parameters with 1,000 replicates, and bootstrap results were applied to the best tree recovered in the RAS search. 
Table 2. GenBank accession numbers for adesmiine sequences used in the ML analysis.

\begin{tabular}{|c|c|c|c|}
\hline Species & GenBank & GenBank & GenBank \\
\hline & $\operatorname{cox} 1$ & $\cos 2$ & H3 \\
\hline Onymacris brainei & MF459686 & MF459688 & MF459690 \\
\hline Onymacris brainei & MF459687 & MF459689 & - \\
\hline O. bicolor & JX448896 & JX448934 & JX448972 \\
\hline O. marginipennis & JX448907 & JX448945 & JX448983 \\
\hline O. langi cornelii & JX448900 & JX448938 & JX448976 \\
\hline O. langi meridionalis & JX448909 & JX448947 & JX448985 \\
\hline O. langi visseri & JX448921 & JX448959 & JX448997 \\
\hline O. boschimana & JX448897 & JX448935 & JX448973 \\
\hline O. multistriata & JX448912 & JX448950 & JX448988 \\
\hline O. hottentota & JX448901 & JX448939 & JX448977 \\
\hline O. plana & JX448915 & JX448953 & JX448991 \\
\hline O. lobicollis & JX448906 & JX448944 & JX448982 \\
\hline Opaiva & JX448913 & JX448951 & JX448989 \\
\hline O. rugatipennis & JX448917 & JX448955 & JX448993 \\
\hline O. laeviceps & JX448904 & JX448942 & JX448980 \\
\hline O. u. unguicularis & JX448919 & JX448957 & JX448995 \\
\hline O. u. schulzeae & JX448920 & JX448958 & JX448996 \\
\hline Physadesmia globosa & JX448887 & JX448925 & JX448963 \\
\hline Eustolopus octoseriatus & JX448886 & JX448924 & JX448962 \\
\hline Adesmia cribripes & JX448889 & JX448927 & JX448965 \\
\hline
\end{tabular}

\section{Results}

\section{New locality for Onymacris brainei}

The second locality for Onymacris brainei was discovered on 22 May 2015. Based on the general geographic information provided in Penrith (1984), this new site is estimated to lie - 15-20 km SSW of the type locality (Fig. 2). The second site closely resembles the original locality's physical and ecological description, characterized by vegetated dune hummocks on which nara (Acanthosicyos horridus), an iconic Namib endemic, is the prevalent floristic component. Beetles were observed under and, in some cases, on hummock vegetation.

\section{Elytral color variation}

As noted, Onymacris brainei is diagnosed by the presence of three broad yellow to tan stripes on white elytra. Specifically, this patterning involves a prominent dorsal stripe that is bisected by the elytral suture and flanked by a slightly narrower lateral stripe on either side. All three stripes bear diffuse edges that coalesce anteriorly near the pronotum, taper posteriorly, and terminate at (or just before) the apical declivity. 


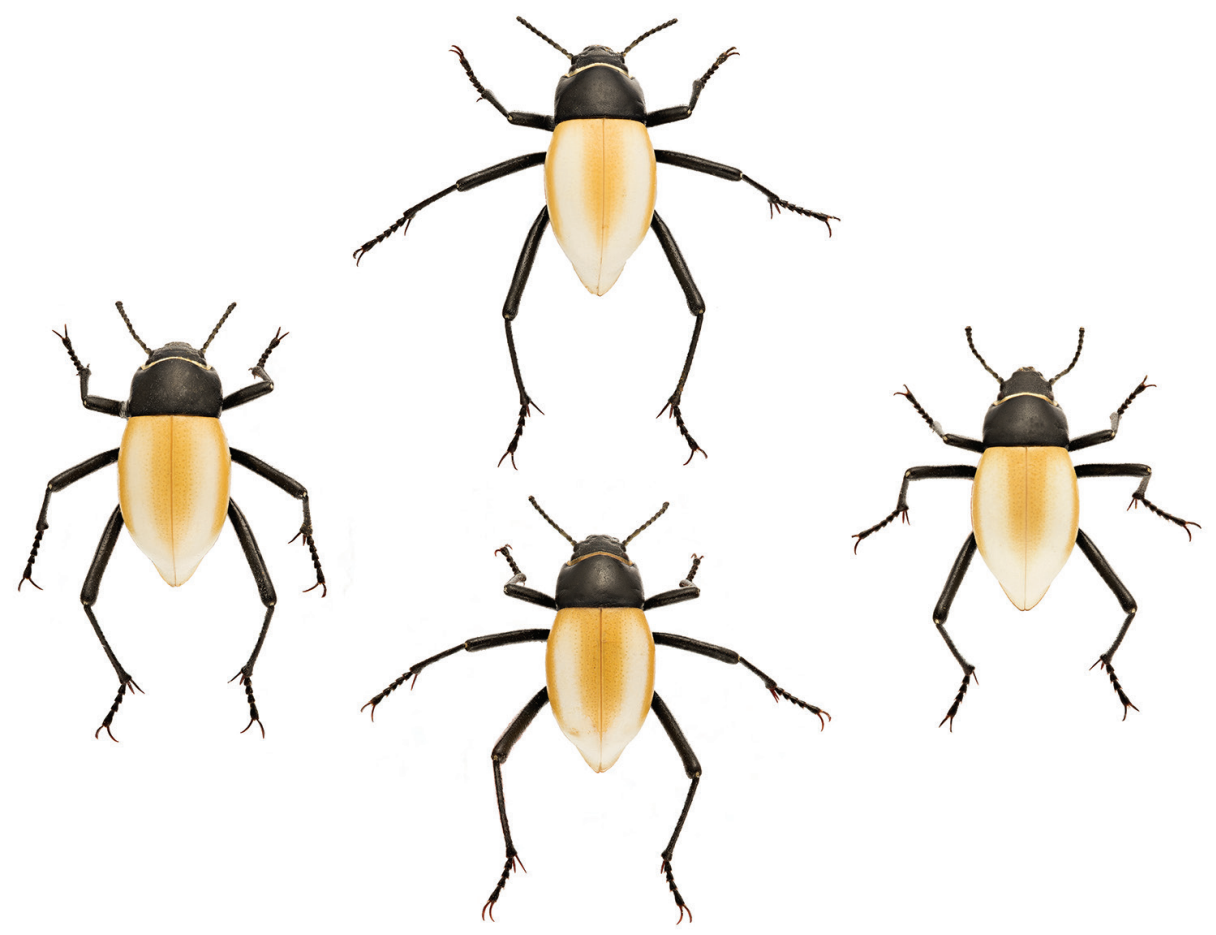

Figure 3. Specimens of Onymacris brainei from the second locality, illustrating variation in degree of elytral striping.

White elytral coloration is not due to any pigment product but rather a function of reflectivity involving microscopic "bubbles" within the cuticle (Kühnelt 1957). Thus, the stripes represent pigment expression within an otherwise colorless elytral matrix. Penrith (1984) noted that both stripe width and degree of pigment suffusion between stripes varied considerably across the type series. Our eight specimens of $O$. brainei exhibit comparable levels of dorsal color variation (Fig. 3).

\section{Genetic variation}

DNA sequences were invariant for the nuclear gene $H 3$ but did exhibit variation for both mitochondrial genes (two haplotypes for each gene); mean sequence divergence for the cox 1 and $\operatorname{cox} 2$ was $1.49 \%$ and $0.05 \%$, respectively.

\section{Molecular phylogenetic placement of Onymacris brainei}

$\mathrm{ML}$ analysis of the concatenated dataset identified $O$. braine $i$ as sister to $O$. marginipennis + O. bicolor in a highly supported clade $(\mathrm{BS}=100 \%)$ that is sister to a second 


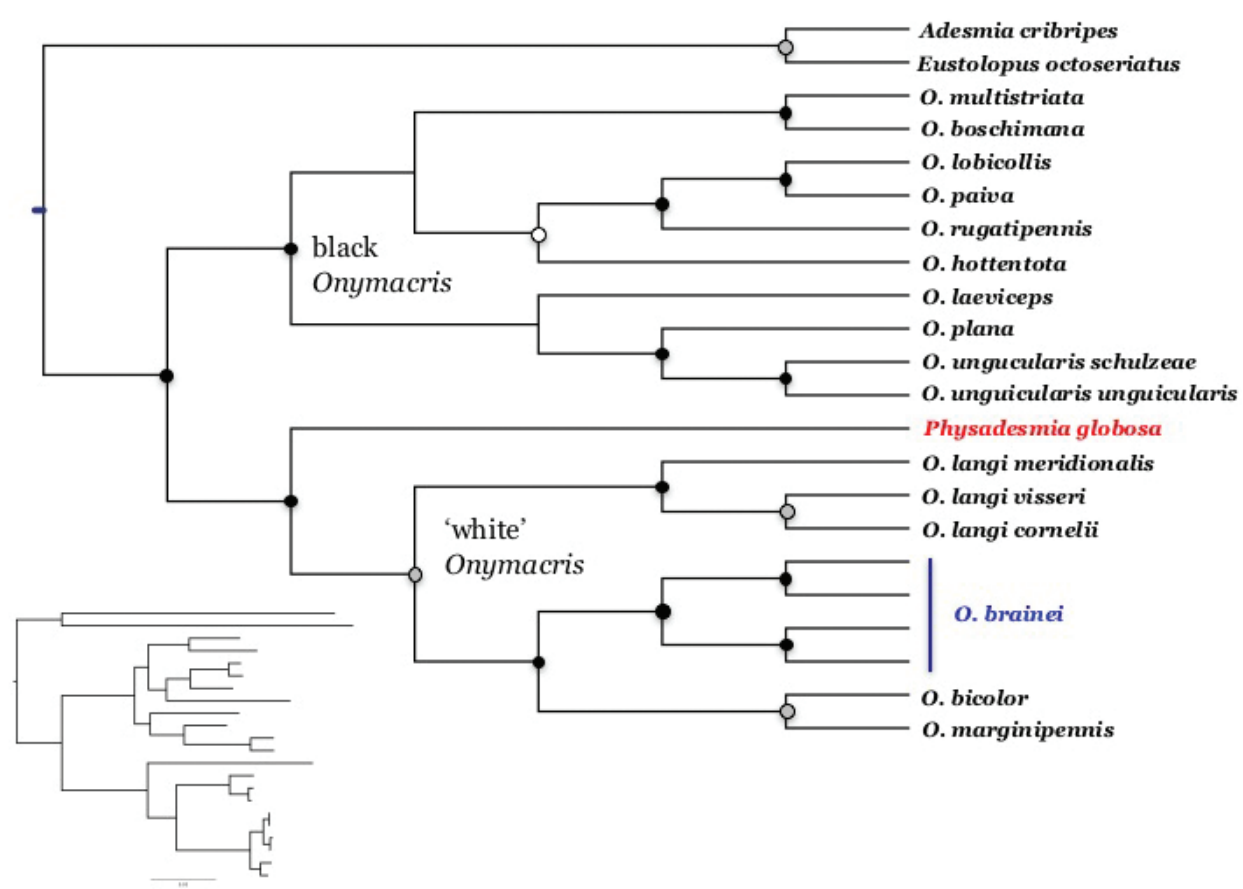

Figure 4. ML consensus topology of Onymacris, with bootstrap support indicated by black (>95\%), gray (>90\%), and white (> 70\%) nodes. Inset at lower left is a ML tree showing branch lengths.

'white' clade comprising the three subspecies of $O$. langi represented in our dataset (Fig. 4). Overall, the ML topology is essentially identical to ML and Bayesian phylogenies previously derived from a larger multilocus dataset (Lamb and Bond 2013), which not only identified two distinct, well supported clades - one containing all 'white' species, the other, exclusively black species - but also revealed that Onymacris is paraphyletic. All three phylogenies [i.e., this report; Lamb and Bond (2013)] depict Physadesmia globosa as the sister taxon to the "white" Onymacris lineage in a highly supported clade (herein, BS = 99\%).

\section{Discussion}

In her paper originally describing Onymacris brainei, Penrith (1984) also reported the first cladistic analysis for the genus Onymacris, based on 23 morphological characters. To her credit, she examined several additional characters but rejected them "owing to suspected parallelism" or because "the direction of development could not be ascertained." Her analysis recovered two major clades: an all-black clade comprising six species (O. boschimana, O. laeviceps, O. lobicollis, O. multistriata, O. paiva, O. rugatipen- 
nis), and a second clade composed of three additional black species ( $O$. hottentota, $O$. plana, O. unguicularis) and the 'white' species group. Regarding relationships within Penrith's 'white' group, O. brainei was placed with $O$. bicolor and O. marginipennis, united by the loss of pseudopleural crests along the elytral margins. Furthermore, Penrith's cladogram depicts $O$. brainei and $O$. marginipennis as sister species on the basis of one synapomorphy-the epistome bearing a deep median emargination.

Our ML phylogeny corroborates bicolor-brainei-marginipennis monophyly but differs by depicting $O$. bicolor and $O$. marginipennis as sister species. To this end, we note a preliminary aspect of the molecular results-our somewhat limited geographic representation for $O$. bicolor and $O$. marginipennis. Relative to the other 'white' taxa, both these species have extended ranges and were recognized historically as being polytypic (Péringuey 1885; Koch 1952). Indeed, O. bicolor was for some time treated as two separate species (Koch 1952; Penrith 1975). Thus, while the precise sister status of $O$. brainei remains equivocal (pending further geographic sampling of $O$. bicolor and $O$. marginipennis, particularly Angolan populations), the strongly-supported monophyly of $O$. bicolor $+O$. brainei $+O$. marginipennis is unlikely to change.

The molecular phylogenetic placement of $O$. brainei with other 'white' Onymacris not only offers incremental support for the 'white' clade but, more broadly, augments a diphyletic Onymacris relative to Physadesmia (Lamb and Bond 2013). Penrith (1979) described the genus Physadesmia for three species [Physadesmia globosa (Haag), P. bullata (Péringuey), and P. aculeata (Péringuey)] formerly in Physosterna. (Of note, Physosterna was subsequently reduced to a subgenus of Adesmia (Penrith 1986)). She also observed that "Physadesmia and Onymacris are evidently very closely related, being separated only by the hypertrophy of the spurs and claws and the shortening of the tarsi in Onymacris." Support for her observation was provided in the first cladistic analysis of adesmiine genera, which recovered a clade comprising Onymacris, Physadesmia, and a third genus, Eustolopus (Penrith 1986). A refined phylogenetic view of Onymacris-Physadesmia, revealed herein and earlier (Lamb and Bond 2013), identifies a need for nomenclatural changes that will reflect the new found relationship between white Onymacris and Physadesmia. However, molecular genetic data are still missing for key taxa: two white Onymacris (O. langi langi and $O$. candidipennis, the latter being the type species of the genus) as well as the remaining two species of Physadesmia (P. bullata and $P$. aculeata). Though recognizing the necessity for taxonomic change (i.e., either subsuming Physadesmia or assigning the black species of Onymacris to a new genus), we consider this move to be premature at present and refrain from such effort until relationships for the remaining few species of Onymacris and Physadesmia have been thoroughly explored.

"Rediscovery" is a beguiling catchword, conveying equal parts accomplishment and optimism upon finding species thought to be rare or possibly extinct. We were indeed relieved to locate new specimens of $O$. brainei-a species gone unreported for 33 years. However, a claim of rediscovery might be overstated: the hiatus is attributable in large degree to the northern Namib's remote setting and limited accessibility. A more telling discovery may be the genetic divergence $(1.49 \%$, cox 1$)$ observed among individuals at the new locality, which could possibly indicate a historically 
larger geographic distribution. It is worth noting that $O$. candidipennis, once thought to be restricted to the Namib's northern terminus in Angola, has been reported from Namibia at the Cunene River, near the type locality for O. brainei (Penrith 1984). Moreover, $O$. bicolor and $O$. marginipennis, the two species most closely related to $O$. brainei, occur on both sides of the Cunene. Thus, future assessment on the status of $O$. brainei (regarding genetic variation as well as range delimitation) should involve surveys of suitable habitat from the type locality west to the Cunene mouth, in Angola as well as Namibia. Close proximity of both type and new localities to the contiguous Skeleton Coast (Namibia) and Iona (Angola) national parks offers promise that additional populations of $O$. brainei might be discovered within park boundaries, where they would be afforded full protection.

\section{Acknowledgements}

We thank Patrice Bouchard, Edie Jeffreys, and Mike Wooten for their assistance in the field. Michael Brewer graciously provided access to his laboratory's composite imaging system. Specimens were processed under Research/Collecting Permit \# 2015/2015 provided by Namibia's Ministry of Environment and Tourism. Funding for this project was provided by Research and Exploration grant \# 9582-14 from the National Geographic Society.

\section{References}

Endrödy-Younga S (1978) Coleoptera. In: Werger MJA (Ed.) Biogeography and Ecology of Southern Africa. Junk, The Hague, 797-821. https://doi.org/10.1007/978-94-009-9951-0_26

Hamilton WJ, Seely MK (1976) Fog basking by the Namib Desert beetle Onymacris unguicularis. Nature 262: 284-285. https://doi.org/10.1038/262284a0

Hanrahan SA, Seely MK (1990) Food and habitat use by three tenebrionid beetles (Coleoptera) in a riparian desert environment. In: Seely MK (Ed.) Namib Ecology: 25 Years of Namib Research. Transvaal Museum Monograph No. 7. Transvaal Museum, Pretoria, 143-147.

Lamb T, Bond JE (2013) A multilocus perspective on phylogenetic relationships in the Namib darkling beetle genus Onymacris (Tenebrionidae). Molecular Phylogenetics and Evolution 66: 757-765. https://doi.org/10.1016/j.ympev.2012.10.026

Larkin MA, Blackshields G, Brown NP, Chenna R, McGettigan PA, McWilliam H, Valentin F, Wallace IM, Wilm A, Lopez R, Thompson JD, Gibson TJ, Higgins DG (2007) ClustalW and ClustalX version 2.0. Bioinformatics 23: 2947-2948. https://doi.org/10.1093/bioinformatics/btm 404

Louw S (1983) The diversity and daily seasonal activity of ground-living Tenebrionidae (Coleoptera) in the southern Namib and Kalahari ecosystems. Cimbebasia A7: 35-56.

Koch C (1952) S. A. Tenebrionidae. XII. Supplementary notes to preliminary articles nos. I, III, V, and VIII. Annals of the Transvaal Museum 22: 79-196. 
Koch C (1962) The Tenebrionidae of southern Africa. XXXI. Comprehensive notes on the tenebrionid fauna of the Namib Desert. Annals of the Transvaal Museum 24: 61-106.

Kühnelt W (1957) Weiss als Strukturfarbe bei Wüstentenebrioniden. Sitzungsberichte der Österreichischen Akademie der Wissenschaften 166: 103-112.

Ogden TH, Whiting MF (2003) The problem with the Paleoptera problem: sense and sensitivity. Cladistics, 19: 432-442. https://doi.org/10.1111/j.1096-0031.2003.tb00313.x

Penrith M-L (1975) The species of Onymacris Allard (Coleoptera: Tenebrionidae). Cimbebasia 4: 47-97.

Penrith M-L (1979) Revision of the western southern African Adesmiini (Coleoptera: Tenebrionidae). Cimbebasia 5: 1-94.

Penrith M-L (1984) New taxa of Onymacris Allard, and relationships within the genus (Coleoptera: Tenebrionidae). Annals of the Transvaal Museum 33: 511-533.

Penrith M-L (1986) Relationships in the tribe Adesmiini (Coleoptera: Tenebrionidae) and a revision of the genus Stenodesia Reitter. Annals of the Transvaal Museum 34: 275-302.

Péringuey L (1885) First contribution to the South African coleopterous fauna. Transactions of the South African Philosophical Society 3: 74-149. https://doi.org/10.1080/2156038 2.1881.9526176

Roberts CS, Seely MK, Ward D, Mitchell D, Campbell JD (1991) Body temperatures of Namib Desert tenebrionid beetles: their relationships in laboratory and field. Physiological Entomology 16: 463-475. https://doi.org/10.1111/j.1365-3032.1991.tb00586.x

Simon C, Frati F, Beckenbach A, Crespi B, Liu H, Paul F (1994) Evolution, weighting, and phylogenetic utility of mitochondrial gene-sequences and a compilation of conserved polymerase chain reaction primers. Annals of the Entomological Society of America 87: 651-701. https://doi.org/10.1093/aesa/87.6.651

Stamatakis A (2006) RAxML-VI-HPC: Maximum likelihood-based phylogenetic analyses with thousands of taxa and mixed models. Bioinformatics 22(21): 2688-2690. https:// doi.org/10.1093/bioinformatics/btl446 